〔110〕ポリエチレンの微細構造に関する研究

第 2 報 直鎖ポリエチレンの結晶化に対する分子量の影響について

(1962 年 5 月 10 日受理)

小島寬男* ・ 山口金哉*

要 旨 分岐のない Marlex 6000 系ポリエチレンの分別および末分別試料の数平均分子量 $\left(M_{n}\right)$ ，重

量平均分子量 $\left(\boldsymbol{M}_{w}\right)$ ，溶液粘度上急冷フィルム試料の結晶化度 $(X \%)$ との関係索調へ，(1)式あるいは $(2)$ 式

$$
X=146 .{ }_{4}-13.7 \log M_{n}-13 .{ }_{7}\left(\log \frac{M_{w}}{M_{n}}\right)+3.0\left(\log \frac{M_{w}}{M_{n}}\right)^{2}
$$

$$
\log X=2.255-0.072 \log M_{n}-0.089\left(\log \frac{M_{w}}{M_{n}}\right)+0.027\left(\log \frac{M_{w}}{M_{n}}\right)^{2}
$$

のような実験式在得た。また未分別 Marlex 6000 系ポリエチレンの急冷シート試料を $120 \sim 130^{\circ} \mathrm{C}$ の液中で アニーリングした場合の見かけの結晶化速度を求め，アニーリングにる結晶化の見かけの活性化エネルギー $(E \mathrm{cal} / \mathrm{mol})$ と重量平均分子量 $\left(M_{w}\right)$ との間に(3) 式のような実検式が成立することを見出した。市販の

$$
\log E=2.02+0.37 \log M_{w}
$$

Marlex 6000 系列について求めた $E$ の值は $7.5 \sim 8.5 \mathrm{kcal} / \mathrm{mol}$ であり, Collins が核磁気共鳴法によって得 た非晶城におうする分子鎖の自己㹡散の活性化エネルギー $8.7 \mathrm{kcal} / \mathrm{mol}$ ときわめて近い値を示している。

\section{1. 楮言}

直鎖状ポリェチレンの結晶化度あるいは密度と分子量 との関係を, 分別試料についてはすでに Tung ${ }^{1), 2)}$ が報 告しているが，平均分子量だけでなく分子量分布も結晶 化に対して影響するものと予測されるので, ここでは分 岐のないフィリップス法ポリエチレンの分別試料抢よび 分子量分布の異なる未分別試料の数平均分子量, 重量平 均分子量, 溶液粘度および分子量分布と結晶化度の関係 について比較実験した結果を報告する。

\section{2. 実験および测定方法}

\section{1 分別実験}

良溶媒として沸点 $136 \sim 139^{\circ} \mathrm{C}$ のキシレンを, 貿溶媒 としては沸点 $133 \sim 135^{\circ} \mathrm{C}$ のエチル七ロソルブを用いて,

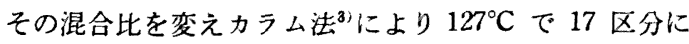
分け，各区分をメタノールで沈殿させてロ過洗浄したの ち減圧乾嬠して分別試料を調製した。

なおポリェチレンとしては Marlex 6000-Type 9 を 用い, $130^{\circ} \mathrm{C}$ で $5 \mathrm{~g} / l$ のキシレン溶液とし,これを $100 \mathrm{~g} / l$ のセライトとよく混合したのち徐椧してポリマーをセラ イトに固着させたものをカラムに充てんした。分別試料 の回收率は $97 \%$ であったが，得られた 17 区分の中か ら成型および測定可能な範囲の 11 区分を選びフィルム 試料をプレス成型して実験に供した。

各区分の $M_{w} / M_{n}$ は $1.1 \sim 1.5$ 程度であり, Tung ${ }^{1)}$

\footnotetext{
* 昭和電工株式会社中央研究所 (東京都大田区原町 501)
}

の得た $1.2 \sim 1.5$ と同程度である。

\section{2 溶液粘度および重量平均分子量の求め方}

$130^{\circ} \mathrm{C}$ において $0.07 \sim 0.12 \mathrm{~g} / 100 \mathrm{cc}$ のテトラリン溶 液の inherent viscosity $\{\eta\}$ を求め (1) 式および (2) 式 によって, 分別試料および末分別試料の重量平均分子量 $M_{w}$ を算出した。なお溶液濃度を $C$, relative viscosity を $r_{r}$ とすれば $\left\{\eta_{i}\right\}=\left(\ln \eta_{r}\right) / C$ であり，Tung ${ }^{7)}$ も報告 しているが，本実験程度の浱度では inherent viscosity と intrinsic viscosity とは近似的に等しいとみなしう ることを確認した。 また(1) 式は小寺)の式に

$$
[\eta]_{\text {tetrallne }}^{180^{\circ} \mathrm{C}}=1.28[\eta]_{a-c h l o r o n a p h t h a l e n e}^{1300^{\circ} \mathrm{C}}
$$

を代入して変換したものであり，(2) 式は Stacy ${ }^{5)}$ が Marlex 6000 系列の末分別試料について提出したもので ある。

$$
\begin{aligned}
& {[\eta]=4.71 \times 10^{-4} M_{w}^{0.71}} \\
& {[\eta]=3.8 \times 10^{-4} M_{w}^{0.72}}
\end{aligned}
$$

\section{3 数平均分子量の求め方}

直鎖状フィリップス法ポリエチレンの各分子の一端に は必ず末端ビニル基が存在するとして, 赤外吸収スペク トル法によって末端ビニル基含量 [Vinyl] \%を求め, (3) 式から数平均分子量 $M_{n}$ を算出した。

$$
M_{n}=\frac{2808}{[\text { Vinyl] }}
$$

なお [Vinyl] \% は $[-\mathrm{C}=\mathrm{C}] \%$ であり, $11.0 \mu$ の吸収 
から (4) 式によって求めた ${ }^{6)}$ 。

$$
[\text { Vinyl }]=K_{11.0} \times \frac{24}{121 d}=0.1985 \frac{K_{11.0}}{d}
$$

また試料の厚さ $d(\mathrm{~mm})$ は $2.35 \mu$ のメチレン鎖の吸 収を内部標準にとり,さらに比容 $V(\mathrm{cc} / \mathrm{g})$ を用いて (5) 式によって求めた。

$$
d=0.4377 K_{2.85} V
$$

な掞 (3) 式によって求めた $M_{n}$ と分別試料について 測定した $\{r\}$ とからきわめてよい近似で $(6-a)$ 式が得 られるが、これは Tung ${ }^{7)}$ が提出した (6-b) 式ときわめ てょい一致を示すものである。

$$
\begin{aligned}
& \{r\}=5.05 \times 10^{-4} M_{n}^{0.72} \\
& {[\eta]=5.10 \times 10^{-4} M_{n}^{0.725}}
\end{aligned}
$$

したがってフィリップス法の分岐のない直鎖ポリェチ レンの数平均分子量は, 赤外吸収スペクトル法によって 末端ビニル基が各分子に 1 個ずつついているとして求め られることが明らかになった。

\section{4 結晶化度の求め方}

水 イソプロピルアルコール系の密度勾配管法によっ て $20^{\circ} \mathrm{C}$ に扔ける比容 $V(\mathrm{cc} / \mathrm{g})$ を求め, (7-a) 式帛によ って質量分率としての結晶化度 $X_{m}$ を算出しうること を先に報告したが，この式を(7-b) 式のように変換して， 質量百分率としての結晶化度 $X(\%)$ を求めた。

$$
\begin{aligned}
& V=1.233\left(1-X_{m}\right)+1.009 X_{m} \\
& X=550.4-446.4 V
\end{aligned}
$$

密度の測定に用いたフィルム試料は未端ビニル基の測 定に供したものと同一であり、粉末試料を写真用フェ口 板の間において厚さ $0.05 \sim 0.1 \mathrm{~mm}$ に加熱プレス成型 したのち，水冷プレスで急椧したものである。

加熱成型温度は分子量に上って溶融粘度が著しく買な るので, $120 \sim 180^{\circ} \mathrm{C}$ の間で選定した。加熱成型温度は 試料の融点以上であり,なおかつ $200^{\circ} \mathrm{C}$ 以下であ扎ば 3 分内外の成型時間中に試料の少化は起こらず，加熱成型 温度に上って急椧試料の密度に変化がみられないことを 別に確認しておいた。

㭅分別シート試料は同様にして $180^{\circ} \mathrm{C} て ゙$ 厚さ約 $1 \mathrm{~mm}$ に加熱成型したのち，水椧プレスで急泠したものについ て密度を測定した。

\section{5 アニーリンク実験法}

加熱プレスで $1 \mathrm{~mm}$ 厚に成型したのち, 直ちに水冷 プレスに移して急冷した陚料をアルミニゥムハクで密に 包んで, 所定温度に対して $\pm 0.2^{\circ} \mathrm{C}$ 以内に調節したシリ コーン油槽中に沙漬してアニーリングを行ない，所定時 間後に取り山してそのまま直ちに汾水中に投人して急冷 した試料について密度を測定し，(7-b) 式によって結晶 化度を算出した。

アニーリング温度は $120^{\circ} \mathrm{C}$ から $2.5^{\circ} \mathrm{C}$ 扰きに $130^{\circ} \mathrm{C}$ までとし， アニーリング時間は 1 1,440 分の間で 7〜 10 点選定した。

溶融状態からの急冷試料を室温 $\left(20^{\circ} \mathrm{C}\right)$ に放置すると 指数関数的に密度がわずかに增加するが，1 カ月後でも 結晶化度に換算して $0.5 \%$ 以内しか増大しないので, 今 回の実験ではアニーリング開始および密度測定までの放 置時間を $1 \sim 3$ 日とした。

\section{3. 実験結果および考察}

\section{1 分子量および分子量分布の影㸷}

分別試料を 2.1 でのべたように調製し, 第 5 区分 (F5) から第 15 区分 (F-15) までを実験に供した。

未分別試料としては Marlex 6000-Type 50, Type 35, Type 15, Type 9 および Type 2 (以下 T 50, T 35, T 15, T 9 および T 2 と略記する)ならびに市販さ れていない高粘度の Marlex 6000 系列の中から 2 試料 (以下 P 6 および P 5 と略記する)を実験に用いた。

さらにP 6 にT 50 をそれぞれ $10,20,30$ および $60 \mathrm{wt}^{\circ} \%$ ロール機で溶融混練したもの,ならびに P 6 と T 50 の素練試料についても実験した。ロール温度は溶 融試料の粘度によって異なり，140 160 ${ }^{\circ} \mathrm{C}$ の間で選定 した。酸化防止剤を含んでいるので 10 分間の素練ある いは混練時間中に酸化されないことを赤外吸収スペクト ルによって確認した。

上述の 24 試料について 2.4 で述べたよらなフィルム 試料を調製して密度を測定し, 結晶化度を算出した結果 を Table 1 に示寸。

分子量の增大上上もに結晶化度が低下寸る傾向が認め られるが，分子量分布によってもかなり異なることが Fig. 1 2 によって明らかである。

Fig. 1 および Fig. 2 にプロットした結晶化度は溶融 状態から急冷したフィルム試料について求めたものであ り, 当然のことながら他の結晶化条件の場合には結晶化 度のみならず相対的な関係も異なるが，ここでは急冷試 料についてのみ実験した結果を報告する。

Fig. i 㧍よび Fig. 2 の直線関係から結晶化度 $X(\%)$ と $M_{n}$ および $M_{w}$ との関倸式を求めると, 分別試料に ついて (8-a) 式と (8-b) 式が得られ, 未分别試料につ いては (9-a) 式と (9-b) 式が得られる。

$$
\begin{aligned}
\text { 分別試料: } & X=145_{.5}-13 .{ }_{7} \log M_{n} \\
& X=146 .{ }_{.}-13.7 \log M_{w} \\
\text { 未分別試料: } & X=135_{.1}-13.7 \log M_{n} \\
& X=1499_{8}-13.7 \log M_{w}
\end{aligned}
$$


Table 1. Effects of inherent viscosity and molecular weight distribution on crystallinity in fractionated and unfractionated Marlex 6000 series polyethylene.

\begin{tabular}{|c|c|c|c|c|c|c|c|c|}
\hline \multirow{2}{*}{\multicolumn{2}{|c|}{ Sample*1 }} & $\multirow{2}{*}{r_{i}}^{* 2}(\mathrm{dl} / \mathrm{g})$ & \multirow{2}{*}{$M_{w} \times 10^{-4}$} & \multirow{2}{*}{$M_{n} \times 10^{-4}$} & \multirow{2}{*}{$M_{w} / M_{n}$} & \multirow{2}{*}{$\begin{array}{c}\text { Crystallinity } \\
X(\%)\end{array}$} & \multicolumn{2}{|c|}{ Crystallinity (\%) } \\
\hline & & & & & & & From eq. (13) & From eq. (14) \\
\hline $\mathrm{F}$ & 5 & 0.477 & 1.71 & 1.26 & 1.36 & 89.1 & 88.5 & 88.8 \\
\hline $\mathrm{F}$ & 6 & 0.579 & 2.25 & 1.87 & 1.20 & 86.8 & 86.8 & 87.2 \\
\hline $\mathrm{F}$ & 7 & 0.671 & 2.77 & 2.52 & 1.10 & 85.4 & 85.6 & 86.0 \\
\hline $\mathrm{F}$ & 8 & 0.743 & 3.19 & 2.99 & 1.07 & 84.8 & 84.8 & 85.2 \\
\hline $\mathrm{F}$ & 9 & 0.861 & 3.93 & 3.51 & 1.12 & 83.7 & 83.5 & 83.8 \\
\hline $\mathrm{F}$ & 10 & 0.962 & 4.59 & 4.10 & 1.12 & 82.4 & 82.6 & 82.9 \\
\hline $\mathrm{F}$ & 11 & 1.09 & 5.48 & 4.59 & 1.19 & 78.0 & 81.5 & 81.8 \\
\hline $\mathrm{F}$ & 12 & 1.31 & 7.10 & 6.60 & 1.08 & 80.7 & 80.0 & 80.4 \\
\hline $\mathrm{F}$ & 13 & 1.97 & 12.6 & 8.59 & 1.47 & 77.0 & 76.6 & 76.8 \\
\hline$F$ & 14 & 3.30 & 26.1 & 18.2 & 1.43 & 72.0 & 72.2 & 73.0 \\
\hline $\mathrm{F}$ & 15 & 6.85 & 72.9 & 50.0 & 1.46 & 68.1 & 66.2 & 67.7 \\
\hline$T$ & 50 & 1.36 & 8.63 & 0.98 & 8.8 & 79.1 & 81.4 & 80.9 \\
\hline $\mathrm{T}$ & 35 & 1.46 & 9.52 & 1.05 & 9.1 & 80.4 & 80.9 & 80.4 \\
\hline $\mathrm{T}$ & 15 & 1.70 & 11.8 & 1.03 & 11.5 & 79.0 & 80.3 & 79.8 \\
\hline $\mathrm{T}$ & 9 & 1.88 & 13.5 & 1.15 & 11.7 & 78.6 & 79.5 & 79.1 \\
\hline $\mathrm{T}$ & 2 & 2.44 & 19.4 & 1.37 & 14.2 & 78.4 & 77.9 & 77.7 \\
\hline $\mathrm{P}$ & 6 & 3.46 & 31.6 & 2.74 & 11.5 & 74.8 & 74.4 & 74.4 \\
\hline $\mathrm{P}$ & 5 & 9.64 & 131.0 & 2.89 & 45.3 & 72.1 & 70.8 & 72.5 \\
\hline MI & 100 & 1.42 & 9.2 & 1.02 & 9.0 & 79.2 & 81.2 & 80.5 \\
\hline M & 60 & 2.29 & 17.8 & 1.36 & 13.1 & 79.5 & 78.2 & 77.9 \\
\hline M & 30 & 2.93 & 25.0 & 1.82 & 13.7 & 77.0 & 76.3 & 76.2 \\
\hline M & 20 & 3.10 & 27.1 & 2.06 & 13.2 & 76.0 & 75.8 & 75.6 \\
\hline M & 10 & 3.33 & 29.9 & 2.36 & 12.7 & 74.9 & 75.0 & 75.0 \\
\hline M & 0 & 3.59 & 33.2 & 2.77 & 12.0 & 75.0 & 74.3 & 74.2 \\
\hline
\end{tabular}

*1 F : fractionated, $T$ and $P$ : unfractionated, $M$ : mixed, $T 50$ and $P 6$ on hot roll mill

*2 $\{r\}$ : inherent viscosity of tetralin solution at $130^{\circ} \mathrm{C}$

*3 $X=550.4-446.4 \mathrm{~V} ; V=$ specific volume $(\mathrm{cc} / \mathrm{g})$ at $20^{\circ} \mathrm{C}$

実験に供した分別試料の， $M_{u} M_{n}$ の平均值は 1.23 で あり， 18-a) 式と (8-b) 式を連立させて求めた $M_{w} / M_{n}$ の值は 1.16 となり, 末分別試料の中 P 5 を除いた $M_{w}$ $M_{n}$ の平均值は 11.8 で，(9-a) 式と (9-b) 式加求め られる $M_{w} / M_{n}$ は 11.7 で当然のことながらよく一致 する。

結晶化度と $\left\{r_{r}\right\}_{i \text { l, r }}$ の関係はほとんど $M_{w}$ について と同様な傾向なので図示しないが，分別試料と末分別試 料について関係式を求めると，それぞれ（10) 式拉よび (11) 式が得られる。

分別試料： $X=82.2-19.3 \log \left\{y_{i}\right\}_{\text {inher }}$

未分別試料： $X=84.8-19.0 \log \left\{r_{i}\right\}_{\text {iriler }}$

次に分子量分布の尺度として便宜上 $M_{w} / M_{n}$ をとり,
分別試料および末分別試料に共通な結晶化度 $X(\%)$ と 分子量 $M$ との関係を(12) 式のよ5な型を仮定して試 行錯誤法によって求めた結果 (13-a) 式および (13-b) 式 を得た。

$$
\begin{aligned}
X & =A-B \log M+\sum C_{i}\left(\log \frac{M_{w}}{M_{n}}\right)^{i} \\
X & =146.4-13_{.7} \log M_{n}-13_{7}\left(\log \frac{M_{w}}{M_{n}}\right) \\
& +3.0\left(\log \begin{array}{l}
M_{\prime^{\prime \prime}} \\
M_{\|}
\end{array}\right)^{2}
\end{aligned}
$$

$$
X=146.4-13 ., \log M_{w}+3.0\left(\log \frac{M_{w}}{M_{n}}\right)^{2}
$$




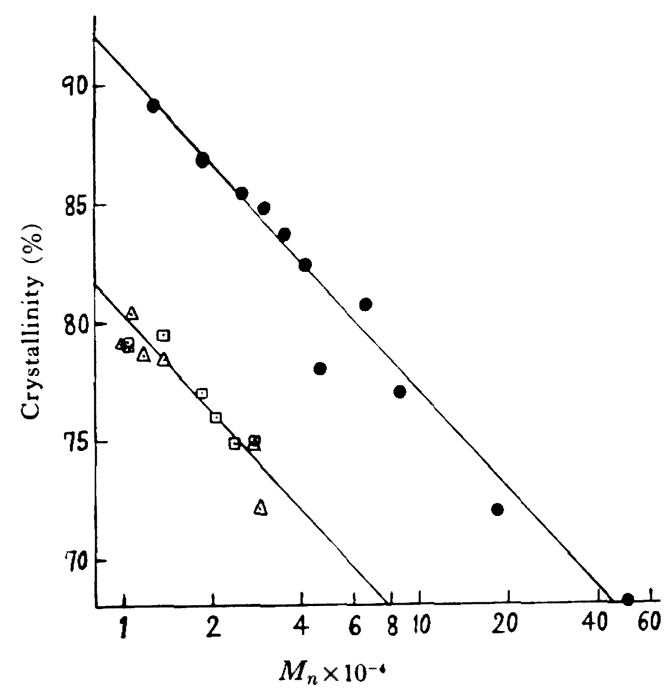

- Fractionated $\Delta:$ Unfractionated

$\square$ : Blended samples of unfractionated Marlex 6000 series

Fig. 1. Variation in crystallinity of quenched film with number average molecular weight.

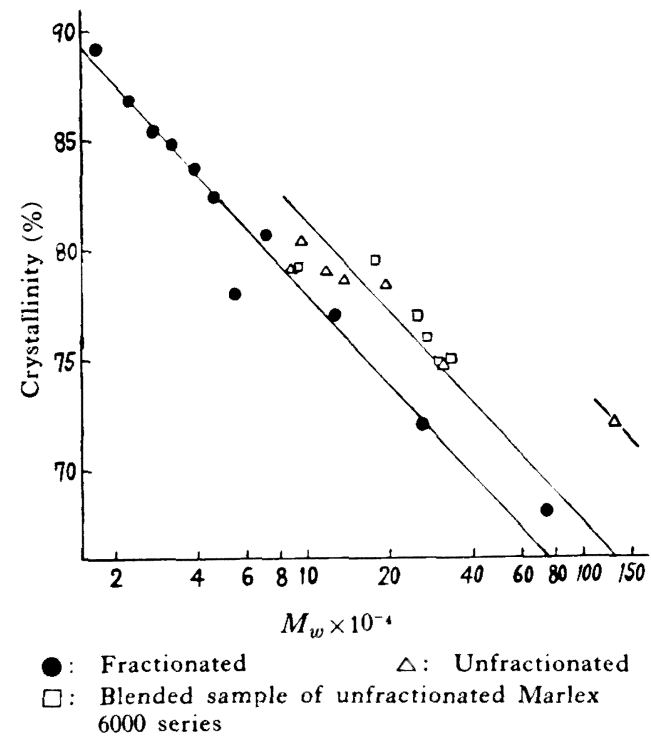

Fig. 2. Variation in crystallinity of quenched specimen with weight average molecular weight.

(13-a) 式と (13-b) 式とは全く同じもので，あくまで も実験式であり, 結晶化条件や分子量分布の形が全く異 なれば (12) 式の $A$ や $B$ の值および $C_{i}$ の值や符号は 変化するものと考えられる。
また Fig. 2 の $M_{w}$ は (1) 式および (2) 式を用いて, $\{\eta\}$ 加換算したものであり，分子量分布の形によって はいくらか不正確になることはさけられない。

なお参考までに (13) 式に $X=100, M_{w} / M_{n}=1$ を代 入して炭素数に換算してみると 174 となり，(8-a) 式と (9-a) 式に $X=100$ を代入して $M_{n}$ を求め,炭素数に換 算すると，それぞれ 150 および 26 となる。

Marlex 6000 系の直鎖ポリエチレンの急冷試料中に も,クリスタリットの $c$ 軸方向の大きさが炭素数にして 100 200 のものが多数認められているので，分子量分 布がきわめて狭、試料では，この程度の炭素数のものは ほとんと $100 \%$ 結晶化するものと推定される。なお Ställberg ら ${ }^{9}$ は炭素数 82 および 100 のノルマルパラ フィンは $100 \%$ 結晶化しらることを見出している。

結晶化度と分子量の関倸は本実験の範囲内では (13) 式のような片対数関倸でなく，(14) 式のような両対数関 係でも表わすことができるが、いずれがより妥当性があ るかの理論的解明はまだできていない。

$$
\begin{aligned}
\log X & =2.255-0.072 \log M_{n}-0.089\left(\log \frac{M_{w}}{M_{n}}\right) \\
& +0.027\left(\log \frac{M_{w}}{M_{n}}\right)^{2}
\end{aligned}
$$

$\log X=2.255-0.072 \log M_{w}-0.017\left(\log \frac{M_{w}}{M_{n}}\right)$

$$
+0.027\left(\log \frac{M_{w}}{M_{n}}\right)^{2}
$$

この場合も (14-a) 式と（14-b) 式とは同じものであ り, $M_{w} / M_{n}=1, X=100$ としたときの 分子量は 3480 となり，炭素数で示すと 248 となる。

分子量と $[\eta]$ との関係に抽いて， $M_{w} / M_{n}$ が大きいほ ど同一 $M_{n}$ に対しては $\left[r_{i}\right]$ が大きくなり，同一 $M_{w}$ に 対しては [ク] が小さいことが知られているが，本実験結 果によれば， $M_{w} / M_{n}$ が大きいほど同一 $M_{n}$ に対して は急冷試料の結晶化度は低く，同一 $M_{w}$ に対しては高 い結晶化度を示している。希薄溶液中の分子鎖の運動性 と溶融状態から急速に泠却される過程で結晶化する際の 分子鎖七グメントの運動性との間にはかなりの差がある にしても，結晶化に際して分子鎖セグメントが結晶配列 をとるための自己拡散性は粘性と負相関関倸にあること が類推されるので, (13) 式や (14) 式の関係は定性的に は成立しうるものといえよう。

\section{2 アニーリングよる結晶化と分子早の関係}

末分別試料 T 50, T 2, P 6 および P 5 について, 2.5 に記した方法でアニーリングを行ないアニーリング 洔間に対して結晶化度をプロットすると Fig. 3 に例示 したよらにアニーリング時間 3 分以後では片対数で直線 


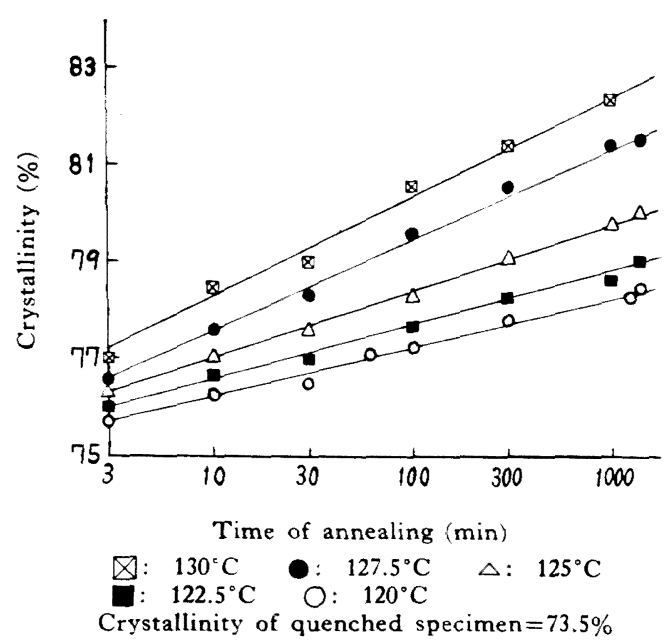

Fig. 3. Rate of crystallinity of quenched linear polyethylene $\left(M_{v}=131 \times 10^{4}\right)$ at various tem. perature of annealing.

関係が得られるので, 各試料について各温度ごとに結晶 化度 $X(\%)$ とアニーリング時間 $t(\mathrm{hr})$ の関係を求める と, (15) 式のような一般式で表わすことができ，(15) 式 の $A$ および $B$ の值は Table 2 のようになる。

$$
X=A+B \log t
$$

そこで $k=B / 2.303$ 上おいて (15) 式を自然対数で表 わすと (16) 式のようになる。

$$
X=A+k \ln t
$$

(16) 式を $t$ で微分すると (17) 式が得られる。

$$
\frac{d X}{d t}=\frac{k}{t}
$$

したがってアニーリングによる結晶化速度は見かけ上 時間 $t$ に逆比例して減少して行くことになる。結晶化が 進むにつれて非晶領域が減少し, 非晶領域にある分子鎖 セク゚メントが結晶配列をとるための自己拡散性が束縛さ れるために見かけ上結晶化速度が低下して行くことは当 然であろう。

絶対温度で示したアニーリング温度の逆数 $1 / T$ に対 して $\ln k$ を Fig. 4 のよ5にプロットした直線から、ア ニーリングによる結晶化の見かけの活性化エネルギーを 求めた結果をもまとめて Table 2 に示した。

T 50 およびT 2 について求めた活性化ェネルギー はそれぞれ $7.5 \mathrm{kcal} / \mathrm{mol}$ 抢よび $8.5 \mathrm{kcal} / \mathrm{mol}$ であり， Collins $^{10)}$ が Marlex 50 について核磁気共鳴吸収法に 上って内部粘性の温度変化から求めた非晶領域における

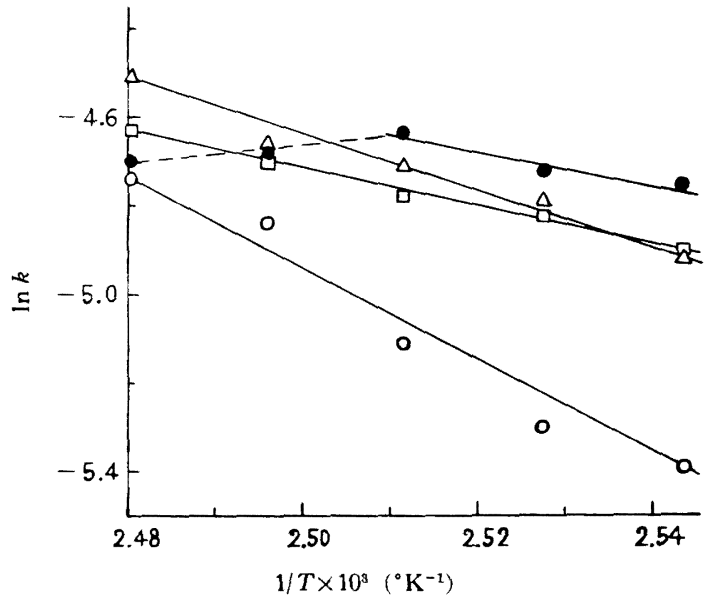

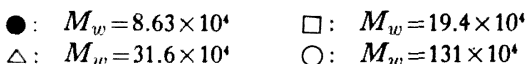

Fig. 4. Variation in apparent rate of crystallization with temperature of annealing for unfractionated Marlex 6000 series.

分子鎖七グメントの自己拡散のための活性化ェネルギー の $8.7 \pm 0.2 \mathrm{kcal} / \mathrm{mol}$ ときわめて近い值を示している。

また Collins ${ }^{11)}$ はアニーリングによる急泠試料の再結 晶化を $25^{\circ} \mathrm{C}, 66.2^{\circ} \mathrm{C}$ および $106.4^{\circ} \mathrm{C}$ で行なわせ, それ ぞれの温度で核磁気共鳴吸収法によって結晶化度を測定 し，アニーリング時間の対数と結晶化度の間に直線関倸 の成立することを認め, われわれと同様な取扱をして活 性化ェネルギーを求めると, 前述の $8.7 \mathrm{kcal} / \mathrm{mol}$ と一 致することを報告している。

なお本実験に用いた末分別試料の節囲内では重量平均 分子量 $M_{w}$ と活性化ェネルギー $E(\mathrm{cal} / \mathrm{mol})$ との間に 見かけ上 (18) 式の関倸が成立する。

$$
\log E=2.02+0.37 \log M_{w}
$$

また Fig. 4 および Table 2 から明らかなように, 供 試試料中で最低の分子量の $\mathrm{T} 50$ は, $125^{\circ} \mathrm{C}$ 付近を境と して見かけの結晶化速度に対する温度の影響が逆転して いるが,この現象は他の試料に比して微結晶の融解温度 城が低いことならびに低分子量フラクションが相対的に 多いことに起因するものと考えられる。すなわら結晶化 のためには非結晶領城にある分子鎖セグメントの自己拡 散がある程度までは容易に行なわれる必要があり, 既存 の相対的に小さな微結晶の融解がこれを助長すると考え られるけれども, ある温度以上になるとより大きな多数 の微結晶が融解し, しかも T 50 のよ5に分子量の小さ いフラクションが多いと非晶領域にある分子鎖セグメン トの自己拡散が激しくなりすぎるため，かえって結晶配 列を取りにくくなり，全体としての見かけの結晶化速度 
Table 2. Effects of temperature and time of annealing on crystallinity for Marlex 6000 series polyethylene.

\begin{tabular}{|c|c|c|c|c|c|c|}
\hline \multirow{2}{*}{ Sample } & \multirow{2}{*}{$\begin{array}{c}\text { Temperature } \\
\left({ }^{\circ} \mathrm{C}\right)\end{array}$} & \multicolumn{2}{|c|}{$X=A-B \log t$} & \multirow{2}{*}{$\begin{array}{c}d X / d t=k / t \\
k(\%)\end{array}$} & \multicolumn{2}{|c|}{$X=A+C \log t \cdot \exp (E / R T)$} \\
\hline & & $A(\%)$ & $B(\%)$ & & C & $E \mathrm{cal} / \mathrm{mol}$ \\
\hline \multirow{5}{*}{ T 50} & 120 & 87.52 & 1.95 & 0.847 & $2.87 \times 10^{4}$ & 7,500 \\
\hline & 122.5 & 88.14 & 2.05 & 0.890 & & \\
\hline & 125 & 88.90 & 2.23 & 0.968 & & \\
\hline & 127.5 & 89.33 & 2.15 & 0.934 & & \\
\hline & 130 & 88.66 & 2.10 & 0.912 & & \\
\hline \multirow{5}{*}{ T 2} & 120 & 84.82 & 1.72 & 0.747 & $9.17 \times 10^{4}$ & 8,500 \\
\hline & 122.5 & 85.33 & 1.86 & 0.808 & & \\
\hline & 125 & 86.22 & 1.94 & 0.842 & & \\
\hline & 127.5 & 86.87 & 2.09 & 0.907 & & \\
\hline & 130 & 87.70 & 2.25 & 0.977 & & \\
\hline \multirow{5}{*}{ P 6} & 120 & 82.23 & 1.69 & 0.734 & $3.45 \times 10^{8}$ & 12,000 \\
\hline & 122.5 & 82.83 & 1.91 & 0.829 & & \\
\hline & 125 & 83.42 & 2.07 & 0.899 & & \\
\hline & 127.5 & 84.40 & 2.19 & 0.951 & & \\
\hline & 130 & 86.30 & 2.38 & 1.033 & & \\
\hline \multirow{5}{*}{ P 5} & 120 & 77.04 & 1.05 & 0.456 & $1.08 \times 10^{11}$ & 20,400 \\
\hline & 122.5 & 77.49 & 1.15 & 0.499 & & \\
\hline & 125 & 78.11 & 1.39 & 0.604 & & \\
\hline & 127.5 & 79.05 & 1.83 & 0.795 & & \\
\hline & 130 & 80.12 & 2.02 & 0.877 & & \\
\hline
\end{tabular}

$d X / d t:$ rate of crystallization at respective time $(t)$ of annealing, $(\% / \mathrm{hr})$

$E:$ apparent activation energy of crystallization

$R$ : gas constant, $1.987 \mathrm{cal} / \mathrm{deg} \mathrm{mol}$

$T$ : absolute temperature of annealing $\left({ }^{\circ} \mathrm{K}\right)$

$k: B / 2.303, X=A-k \ln t$

が低下するに至ると考えられる。

なお, この実験に 用いた急冷試料の融点(溶け終り温 度)は $2^{\circ} \mathrm{C} / \mathrm{min}$ の年温速度で試料中にサーミスター感熱 体を挿入して常法により融解に伴ら吸熱現象を利用して 自記記録計で測定した結果， T 50 で約 $130^{\circ} \mathrm{C} ，$ T 2 は $131^{\circ} \mathrm{C}, \mathrm{P} 6$ および P 5 では $132^{\circ} \mathrm{C}$ であり, 多数の微 結晶が顕著に溶け始める温度は T 50 で約 $124^{\circ} \mathrm{C}$, T 2 は $125^{\circ} \mathrm{C}, \mathrm{P} 6$ および P 5 では $126^{\circ} \mathrm{C}$ であった。これ らの温度は年温速度 $1 \sim 3^{\circ} \mathrm{C} / \mathrm{min}$ の範囲内ではほとんど 差が認められなかった。

\section{4. 結言}

直鎖状ポリエチレン (Marlex 6000-Type 9) をカラム 法で分別し，赤外吸収スペクトル法で末端ビニル基含量 を求め, 各分子の一端にビニル基が存在するとして算出
した数平均分子量と, 溶液粘度との関係を求めた結果, (6-a) 式を得た。この式は Tung ${ }^{7)}$ が提出した関係式と よい一致を示している。

次に分別および末分別試料を溶融状態から急冷したフ ィルムの結晶化度と分子量および分子量分布の関係を求 め，(13）式および (14) 式を提出した。

さらに末分別試料の急冷シートについて, $120 \sim 130^{\circ} \mathrm{C}$ の液体中に浸漬してアニーリングを行ない，見かけの結 晶化速度を求め, これから見かけの結晶化の活性化エネ ルギーを算出し，実験式として (18) 式を得た。

Marlex 6000-Type 50 および Type 2 についての活 性化エネルギーはそれぞれ $7.5 \mathrm{kcal} / \mathrm{mol}$ および $8.5 \mathrm{kcal} /$ mol であり, Collins ${ }^{10)}$ が核磁気共鳴吸収法によって Marlex 50 について得た $8.7 \mathrm{kcal} / \mathrm{mol}$ とよい一致を示 している。 
付 記：本研究の遂行にあたり，砷論および実験を通じて ご指導ならびにご協力をいただいた高橋彰室長をはじめとする 室員諸氏に深く謝意を表します。

\section{文献}

1) L. H. Tung: SPE Journal, 14, 25 (July, 1959)

2) L. H. Tung, S. Buckser: J. Phys. Chem., 62, $1530(1958)$

3) P. M. Henry: J. Polymer Sci., 36, 3(1959)

4) 小寺 明 et al：日化第 14 年会講演 (April, 1961)
5) C. J. Stacy: Phillips Petroleum Co., Research Div. Rep., 2198-58 R (Oct. 1958)

6) L. H. Cross, R. B. Richards and H. A. Willis: Discuss. Faraday Soc., 235(1950)

7) L. H. Tung: J. Polymer Sci., 24, 333(1957)

8）小島寛男, 安部明広：高化, 18, 728(1961)

9) G. Ställberg, S. Ställberg-Stenhagen, E. Stenhagen: Acta. Chemica Scandinavica, 6, 313(1952)

10) R. L. Collins: J. Polymer Sci., 27, 67 (1958)

11) R. L. Collins: J. Polymer Sci., 27, 75(1958)

\title{
The Studies on the Fine Structures of Polyethylenes
}

\section{On the Effects of Molecular Weight on the Crystallization in Linear Polyethylenes}

\author{
By Hiroo Kojima* and Kin-ya Yamaguchi*
}

The relations of the inherent viscosity $\left\{y_{j}\right\}$, the weight average molecular weight $\left(M_{W}\right)$ and the number average molecular weight $\left(M_{n}\right)$ to the crystallinity $(X \%)$ of the rapidly cooled specimens of fractionated and unfractionated linear polyethylenes (Marlex 6000 series) were studied. The empirical relations among crystallinity, molecular weight and molecular weight distribution parameter, $M_{\mathrm{W}} / \boldsymbol{M}_{n}$ were obtained as follows :

$$
\begin{aligned}
& X=146.4-13 .{ }_{7} \log M_{n}-13 ._{7}\left(\log \frac{M_{W}}{M_{n}}\right)+3.0\left(\log \frac{M_{W}}{M_{n}}\right)^{2} \\
& X=146.4-13 .{ }_{7} \log M_{n}+3.0\left(\log \frac{M_{W}}{M_{n}}\right)^{2}
\end{aligned}
$$

The effects of time and temperature of annealing and of molecular weight on the recrystallization of the quenched specimens of unfractionated Marlex 6000 series have been investigated. These specimens were annealed in the liquid bath at the regulated temperatures, 120, 122.5, 125, 127.5 , and $130^{\circ} \mathrm{C}$, respectively. The crystallinity of annealed specimens was calculated from the density at $20^{\circ} \mathrm{C}$. The recrystallization by annealing is seemed to be represented as the empirical formula, $X=A+B \log t$, where $X$ is the percentage crystallinity and is the time of annealing in hours. The rate of crystallization, $d X / d t$, increased with temperature of annealing except for Marlex 6000 -Type 50 above $125^{\circ} \mathrm{C}$. The temperature-dependence of $B$ was explained by the assumption that the over-all rate of crystallization would be controlled by the diffusion of molecular chain segments in the amorphous region and by the partialy melting of preexistent crystallites. An empirical relation between the apparent activation energy $(E \mathrm{cal} / \mathrm{mole})$ of crystallization by annealing from 120 to $130^{\circ} \mathrm{C}$, and the weight average molecular weight $\left(M_{W}\right)$ was obtained as follows:

$$
\log E=2.02-0.37 \log M_{W}
$$

The values of $E$ for commercial Marlex 6000 series were from 7.5 to $8.5 \mathrm{kcal} / \mathrm{mole}$. These values are similar to the value, $8.7 \mathrm{kcal} / \mathrm{mole}$, obtained in the study of nuclear spin resonance for Marlex 50 by Collins.

\footnotetext{
* Showa Denko Co., Ltd., Central Research Laboratory. (501 Haramachi, Ota-ku, Tokyo)
} 